\title{
Audit of economic security as an effective tool to prevent corruption in a construction company
}

\author{
Larisa Domracheva ${ }^{1}$, Elena Karanina ${ }^{1,{ }^{*}}$, Alexander Bakhtimov ${ }^{1}$, and Maxim Kochetkov ${ }^{1}$ \\ ${ }^{1}$ Vyatka state University, Preobrazhenskaya St., 41, 610020, Kirov, Russia
}

\begin{abstract}
An audit of economic security helps to prevent corruption, as well as an assessment of awareness in the struggle against corruption. Audit can promote the implementation of ways to protect the economy of the construction industry against corruption. The authors pay special attention to the problem of the construction industry in Russia. Practical questions of the audit of economic security, which are considered in the article, solve the problems of financial control in the system of anti-corruption policy. The purpose of this study is to develop an audit mechanism for economic security, as a system to prevent internal and external threats and risks. The main concept of the research is aimed at the formation of an audit of economic security in the construction industry. Effective work to prevent corruption in the relations of construction organizations is ensured by the formation of an internal control system to prevent the causes of corruption in the construction sector. It is necessary to take into account the fact that analysis of risk factors at the level of the operating segment in the construction industry can contribute to the development of this area.
\end{abstract}

\section{Introduction}

Depending on the financial and industrial development, the degree of centralization of management of the economy and the social sphere, the financial control systems in different countries have significant differences.

Compliance by construction organizations with existing legislation, disposal of property entrusted to them should be controlled. That is why in all developed countries such attention is paid to the organization of financial control of all aspects of economic life.

The construction industry in Russia at the present stage of economic development occupies a special place in the sphere of production. Its condition largely determines the level of development of society and its productive forces, has an impact on the development of related industries of material production. This industry has a significant specificity associated with such features of pricing, as a link to normative and estimate bases with various possibilities for recalculation of prices and is intended for renewal of production assets, development and improvement of the social sphere, reconstruction, modernization and technical re-equipment of production.

The role of construction in the economy of Russia is determined not so much by the scale of construction and installation works, but rather by the special significance of the functions performed by it. The main peculiarity of the present period of the functioning of the investment and construction complex (ICS) was: the sharply increased demands for it on the

\footnotetext{
* Corresponding author: kafinanc@yandex.ru
} 
need for increasing volumes, rates and quality of work, ensuring integration processes for entering the world market and achieving high competitiveness of products.

In construction, as in other branches of the national economy of Russia, there was a fairly rapid redistribution of property. The health of the nation, the demographic situation, the strength of the family, the happy childhood, the quality of life, the attitude to power, and much more depend on the security of our citizens in comfortable housing. In 1991, B.Yeltsin, Ye. Gaydar and others undertook reforms for the sole purpose of moving the country out of the socialist "stagnation" and significantly improving the well-being of citizens. The first leaders of the state could not have had a different goal. And this is, above all, a significant improvement in the living conditions of people. In the early 90 's, according to official figures, the volume of housing construction fell more than twofold and by the beginning of the $21 \mathrm{st}$ century it had reached the level of the early 50's. The pace of construction did not correspond at all to the tiny needs of the population in well-equipped apartments. This is the first significant difference in the field of housing construction in the $90 \mathrm{~s}$ from the socialist "stagnation" of the 1980s.

Disadvantages and advantages of the building complex are presented in Table 1.

Table 1. Disadvantages and advantages of construction organizations.

\begin{tabular}{|c|c|}
\hline $\begin{array}{l}\text { Strength sides } \\
\text { - Rich mineral and raw materials base } \\
\text { - Traditions of production of building materials } \\
\text { - The trust of the region's construction organizations to local } \\
\text { producers of building materials } \\
\text { - Developed production base } \\
\text { - Sufficient supply of necessary skills }\end{array}$ & $\begin{array}{l}\text { Weak sides } \\
\text { - Narrowness of the internal market } \\
\text { - High capital intensity of } \\
\text { productions } \\
\text { - Dependence of industries on the } \\
\text { state of the road network } \\
\text { - High level of depreciation of } \\
\text { fixed assets }\end{array}$ \\
\hline $\begin{array}{l}\text { Capabilities } \\
\text {-Steady demand related to construction activity in the region } \\
\text {-The prospect of increasing demand for construction materials } \\
\text { in connection with the implementation of the national project } \\
\text { "Affordable and Comfortable Housing", the development of } \\
\text { mortgage lending, the activity of regional mortgage companies } \\
\text {-Additional inflow of long-term investment resources from } \\
\text { neighboring regions } \\
\text {-Significant reserve capacity }\end{array}$ & \begin{tabular}{|l} 
Threats \\
-Increasing competition from \\
innovative building materials \\
produced outside the Kirov region \\
-Instability of the real estate market
\end{tabular} \\
\hline
\end{tabular}

Based on the conducted research of the construction industry in Russia, it can be concluded that at present for the organizations of this industry the situation is rather complicated, and this is a consequence of the general processes taking place in the country's economy. It should be noted that the current economic situation, characterized by a high degree of competition between construction organizations, the complexity of the application of various taxation systems, necessitates the introduction of an audit of the economic security system and the implementation of anti-corruption measures in construction organizations. The management of the construction organization should be responsible to the owners for creating conditions that ensure the functioning of a quality system of economic security.

\section{Materials and Methods}

The method of audit of economic security, in fact, is a set of methods, techniques, actions that allow the auditor: 1) evaluate the effectiveness of the internal control system based on a risk-based approach; 2) assess the effectiveness of the existing in the organization of the system of economic security and anti-corruption strategy; 3) determine the degree of 
influence of internal and external threats and corruption risks on achievement of the objectives of the entity's activities.

First of all, it is necessary to justify the need to include an evaluation of the anti-corruption strategy in the audit of the economic safety of the construction organization. A retrospective analysis of corruption in Russia allows us to conclude that in all historical periods of its development, under any state structure and type of government, corruption was a national disease. Each historical period has its own characteristic features and belonging to known cultural and historical types of corruption (eastern, western, socialist). [1,2]

The essence of corruption is examined on the basis of various theoretical approaches that make it possible to disclose its content and causes from the positions of economics, politics, psychology, sociology and other sciences. Thus, the explanation of the nature of corruption is contained in the works of Naumov Yu.G. [3], Satarova GA [4], Astaf'eva VA [5], Vannovskoy O.V. [6], O. Karpovich [7] and many others.

In 2013, corruption risks continued to cause serious concern among the heads of international companies. In the United States, more stringent anti-corruption measures are being taken, while in the UK, the Bribery Act (UK Bribery Act) has been in place for three years (since July 1, 2011). Countries such as China, India and Russia have already adopted or are preparing to adopt new amendments and additions to anti-corruption legislation. Given the increased risk of prosecution, more and more companies are developing anti-corruption compliance programs that include anti-corruption policies (anti-corruption policies), financial controls, training programs, internal audit procedures and other monitoring mechanisms $[8,9]$. In our opinion, continuous monitoring, which provides for internal audits, is the most important element of an effective anti-corruption compliance program.

Measures aimed at combating corruption require a wide range of activities, as well as the work of a large number of specialists. Ways of preventing and fighting corruption are closely related, but among them are the following:

- precautionary measures of the first group: integration and cooperation;

- preventive measures of the second group: transparency and accountability;

- Preventive measures of the third group: reduction of risks and opportunities;

- preventive measures of the fourth group: control.

The methods include risk analysis, anti-corruption measures planning, anti-fraud mechanisms in companies, declaration of property owned by government officials and politicians, development of rules for public procurement, documenting of decisions taken, drafting of black lists of companies, journalistic investigation, implementation of the principle of "four eyes", as well as rotation of posts.

So, according to A.E. Sheveleva opinion [10], it seems possible to combine the main causes that led to distortions in reporting and the violation of economic security of corporations into four groups:

1. Artificially overestimating the profitability of a corporation through the implementation of specific transactions or fictitious transactions with subsidiaries, as well as through the widespread use of schemes to optimize taxation.

2. Concealing the facts of the transfer of funds from the parent organization to family companies and the widespread use of offshore zones and a network of shell companies to conceal money leaks.

3. Artificial overstatement of the organization's revenues at the same time as artificial understating of current expenses.

4. Overestimation of the value of the corporation's assets due to non-implementation in 2000-2001. Timely mark-up of equipment that has lost market value due to a collapse in the technology and telecommunications sector.

The Federal Law "About Auditing" obliges auditors to inform the founders of the audited entity, their representatives about the cases of corruption offenses that they have become 
known, including cases of bribery of foreign officials, in some cases inform law enforcement bodies about it.

The international audit standards (MCA) oblige auditors during audit of the financial reporting: 1) to consider observance by an audited person of legislative and other standard legal certificates, including requirements of documents on counteraction of corruption; 2) having carried out the risk assessment procedures, to ascertain whether the organization identifies and evaluates corruption risks. Figure 1 shows the algorithm of actions during the audit of the economic security of the organization (Fig. 1)

The method of audit of economic security is a description and algorithm for the implementation within the construction organization of procedures to be performed during the organization and implementation of control measures aimed at preventing internal and external threats and ensuring the legality, completeness of performance, quality and effectiveness of assessing the effectiveness of elements of economic security systems and activities on counteracting corruption of an audited entity, as well as determining the degree of influence of corruption risk to achieve the objectives of the enterprise. At the same time, the powers of the subjects of control include: the adaptation of the proposed methodology to the operation of the object of control, the development of criteria for assessing the effectiveness and procedure for their calculation.

The protection of information, especially in the economic sphere, is a very specific and important activity. The security of an automated enterprise information system (AISP) is understood as its protection against accidental or deliberate interference in the normal process of its functioning, as well as attempts to steal, modify or destroy its components.

With the right choice of methods for conducting human resources audit, it is worth paying attention to the completeness of the collected information of the workers' personal data. To this end, it is necessary to conduct procedures for auditing interpersonal relations and gender audit.

Audit of interpersonal relations is a systematic analysis of patterns, stereotypes, expectations, attitudes of employees of the organization towards each other and to the company as a whole, aimed at assessing the effectiveness of the existing personnel management system of the company, matching the company's personnel potential, its goals and strategy [11]

As a means of ensuring economic security, the audit also has considerable weight, because with its help it is possible to neutralize tax, economic, managerial and economic and legal threats.

The protection of information, especially in the economic sphere, is a very specific and important activity. The security of an automated enterprise information system (AISP) is understood as its protection against accidental or deliberate interference in the normal process of its functioning, as well as attempts to steal, modify or destroy its components.

With the right choice of methods for conducting human resources audit, it is worth paying attention to the completeness of the collected information of the workers' personal data. To this end, it is necessary to conduct procedures for auditing interpersonal relations and gender audit. To prevent sabotage and terrorist threats against managers and valuable specialists of enterprises (firms) and banks, security services, in conjunction with state law enforcement agencies and private security agencies involved, should build a rather complex and complex system for organizing the personal safety of these individuals, protecting their office and living quarters, means of transport and members of their families who may be subject to moral and physical effects, as well as to become victims of threats and kidnapping.

Taking into account the domestic and foreign experience of personal protection, the security measures can be conditionally divided into the following areas: safety in the workplace; security when leaving (leaving) the territory of the enterprise; safety during mass events; safety of family members and protection of housing. 


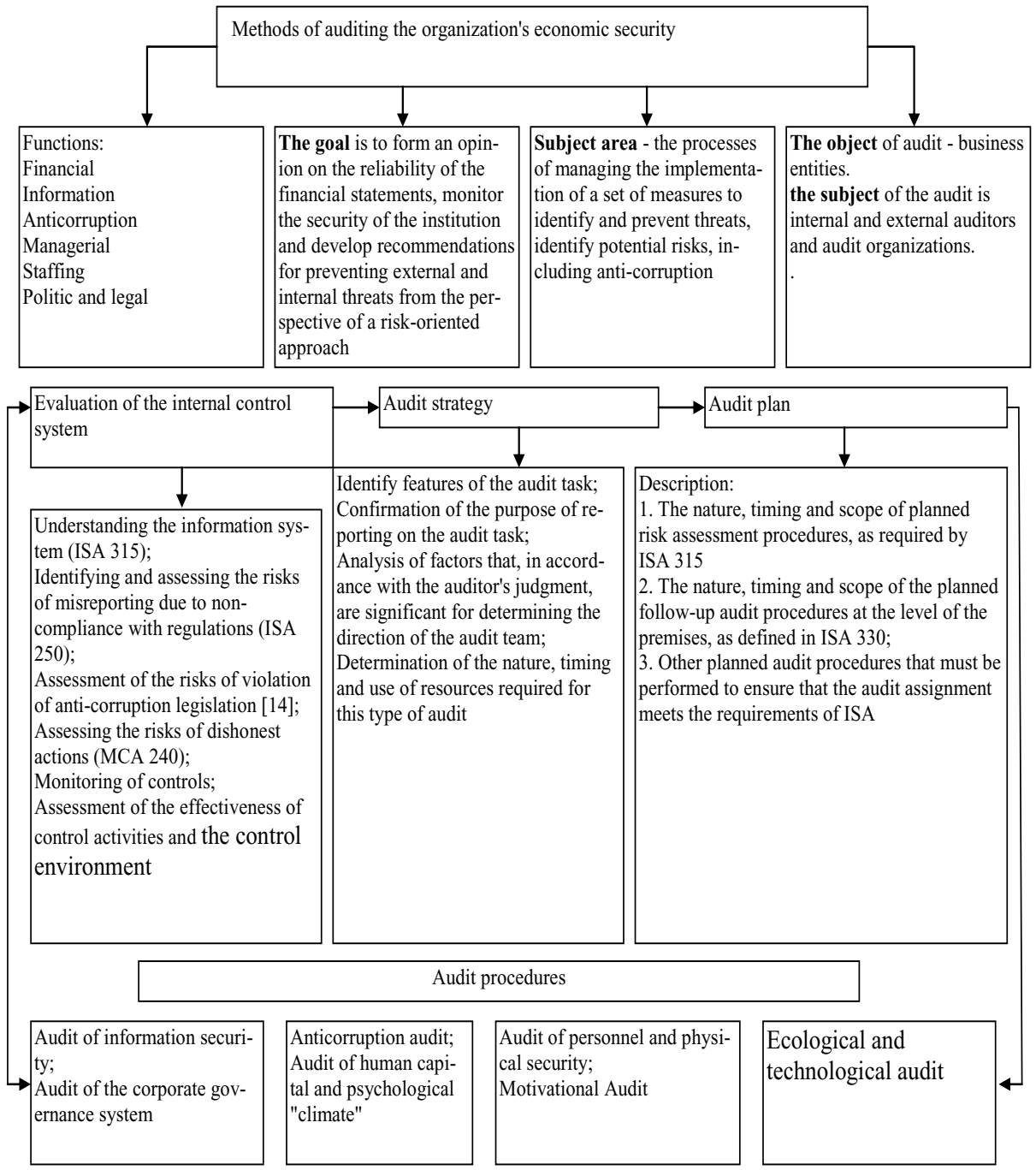

Fig. 1. Methods of auditing the organization's economic security (developed by the authors).

\section{Results}

Over the past few years, the Russian audit has undergone significant changes - legislative, industry, professional. In connection with the transition to international standards, audit has become one of the tools to ensure economic security at various levels of enterprise management. Numerous publications and studies of our foreign colleagues prove the fact that the young audit history of Russia is interesting to the world community.

In 2016, the concept of further development of audit activity was adopted in the Russian Federation, which determined the future development of audit in Russia [12]

According to the Ministry of Finance of the Russian Federation, two self-regulatory organizations remained in the state register of self-regulatory organizations of auditors in the Russian Federation: the Association Russian Union of Auditors and the Association Sodruzhestvo, which, according to data at the beginning of 2018, involved 4226 audit organizations, 654 individual auditors and more than 1,606 certified auditors. 
Based on the results of the first large-scale questionnaire survey of the market of audit services conducted in the research work "Analysis of business activity in the market of audit services in 2015 - 2016", carried out by the Ministry of Finance of Russia in 2016, the following conclusions can be drawn:

- the majority of subjects of the market of audit services assess their economic situation at the beginning of 2016 as "satisfactory" (66.0\%), much less - as "unfavorable" and only $5.7 \%$ consider it "favorable", while more optimistic estimates from individual auditors and large audit organizations: $10.2 \%$ and $10.3 \%$, respectively, consider their economic situation favorable as of the beginning of 2016;

- the first place on demand in the market of audit services among various activities is obligatory audit of other (except for socially significant organizations) clients, on the second - initiative audit;

- business activity in the market of audit services, according to the constructed indices, increased until 2008, and then monotonously fell until 2016; [13]

In the modern version of the audit, the interests of the market and consumers may not meet. The prospect of development is not related to the classic audit of financial statements, but to the forecasts of the development of organizations taking into account the threats to ensure their economic security.

At present, audit issues in the system of economic security are among the most urgent, since the provision of conditions for economic growth of all subjects of legal relations directly depends on their solution.

As one of the areas of audit activity, the audit of the enterprise's economic security system allows the most complete assessment and understanding of the causes of "failures and failures" of business processes, the causes of the resulting losses and shortages, and the conduct of audit procedures will prevent large losses in the future by revising the enterprise development strategy. It is the audit procedures that will determine the degree of ability of the construction organization to minimize threats, both external and internal.

The broader concept of "economic security" presupposes a state of the enterprise that provides the ability to withstand adverse external influences, which makes it possible to ensure its stability in a variety of, including under adverse conditions. In this regard, the concept of "economic security" of the enterprise implies its protection from the negative influences of the external environment, as well as its ability to quickly eliminate various external and internal threats.

In our opinion, economic security is a quantitative and qualitative characteristic of certain properties of an enterprise that reflects the ability of self-repayment and improvement of activities in the face of external and internal economic threats.

In addition, one of the most important links in the system of economic security of an enterprise is its financial component. In essence, audit is universal, as it allows to solve several functions from the economic security structure at once: financial, information, political, legal, anti-corruption, management and personnel. The effectiveness of the implementation of the system approach in the audit of enterprise security in practice depends on the ability of the auditors to promptly identify and objectively analyze all the personal factors and connections of a rather complex object of protection, what state institutions are.

The threat to the economic security of an enterprise is a combination of factors and processes that pose a threat to the development of the enterprise's potential to fulfill its production functions.

The system of financial security indicators allows you to determine the level of future risks and threats, to identify the sources of their spread. In this regard, it becomes possible to develop and implement a set of proactive measures aimed at reducing the level of threats in the financial sphere, as well as to improve its stability, sustainability and efficiency, which underlies competitiveness [14] 
Each indicator of economic security in the range of its possible change should have a fixed threshold (barrier) value.

\section{Discussion}

The threshold value of the indicator is its limiting value, the achievement (or crime) of which indicates a violation of the normal functioning of the enterprise, the manifestation of negative processes that are destructive for the potential and results of the economic activities of the enterprise.

The problems of economic security of a construction organization are among the creative tasks that are solved on the basis of integrated approaches by auditors.

The relationship between the audit of economic security and financial control allows examining the audit as: a) an element of audit of accounting (financial) reporting; b) an independent audit, the content of which is determined by the needs of assessing the effectiveness of the system of economic security and evaluation of anti-corruption measures.

Let's formulate the main elements of the audit of economic security and verification of compliance with the requirements of the anti-corruption legislation, setting it

meaning and purpose: 1) the purpose is to form an opinion on the reliability of financial statements, monitor the organization's economic security system and develop recommendations for preventing external and internal threats from the perspective of a riskoriented approach; 3 ) the subject area - the processes of managing the implementation of a set of measures to identify and prevent threats, identify potential risks, evaluate anticorruption policies 4) the object of the audit - the business entity 5) the subject of the audit internal and external auditors.

Based on the conducted research, we clarified the concept of audit of economic security of a construction organization as an activity for assessing the compliance of an enterprise's economic security system with its strategic objectives and the degree of its ability to minimize threats, followed by an assessment of potential risks and verification of compliance with anticorruption legislation.

Based on the Federal Law "On Auditing" [15], during the audit of 2017, it is necessary to be guided by the international audit standards (ISA), which were enacted in the Russian Federation by the orders of the Ministry of Finance of Russia dated October 24, 2016 No. $192 n$ and 9 November 2016 No. 207n [16,17]

\section{Conclusions}

A prerequisite for overcoming corruption in Russia is objective informing of civil society about the activities of state bodies and local self-government bodies. The prospect of development is not related to the classic audit of accounting statements, but to forecasts of the development of construction organizations in the course of conducting audit procedures to prevent and identify corrupt practices and ensure an effective system of economic security of the enterprise.

\section{References}

1. E.V. Alekhin, E.V. Eremina, Corruption in Russia: a system analysis, Society: sociology, psychology, pedagogy 4 (2016)

2. V.Yu. Golubovsky, T.N. Sinyukova, Forms and types of manifestation of corruption in modern Russian society (Political Linguistics, 2015) 
3. Yu.G. Naumov, Institutional corruption in modern Russia, Proceedings of the Academy of Management of the Russian Ministry of Internal Affairs (2013)

4. M.I. Levin, G.A. Satarov, Corruption in Russia: Classification and Dynamics, http://institutiones.com/general/2129-korrupciya-v-rossii-klasifikaciya-idinamika.html. zagl. from the screen

5. V.A. Astafyev, Corruption as a special form of economic relations in a society, the dissertation author's abstract on competition of a scientific degree of the candidate of economic sciences (2010)

6. O.V. Vannovskaya, Personal determinants of corruption behavior, Izvestiya of the Russian State Pedagogical University A.I. Herzen (2009)

7. O.G. Karpovich, Corruption in modern Russia, http://sartraccc.ru/Pub/karpovich.pdf (2017)

8. E.V. Karanina, Procedia Engineering 165, 972-979 (2016) DOI: 10.1016/j.proeng.2016.11.808

9. E.V. Karanina, IOP Conference Series: Earth and Environmental Science, 90(1) (2017) DOI :10.1088/1755-1315/90/1/012087

10. E. Shevelev, Accounting in the system of economic security of the enterprise (The Economist, Moscow, 2005)

11. L.P. Domracheva, E.V. Lapteva, Publishing Finance and credit, International Accounting 4 (2016)

12. The concept of further development of audit activities in the Russian Federation, www.consultant.ru

13. URL : https://www.minfin.ru/ru/perfomance/audit/audit_stat/MainIndex/

14. Report of the Ministry of Finance about audit activities, http // www.audit.ru / news / audit / 725760

15. E.V. Karanina, Financial security (at the level of the state, region, organization, person), Monograph (FGBOU IN VyatGU, Kirov, 2015)

16. Federal Law No. 307-FZ of 30.12.2008, http://www.consultant.ru

17. Order of the Ministry of Finance of Russia on October 24, 2016 No. 192n, On the enactment of international standards for auditing in the territory of the Russian Federation, http: minfin.ru 